\title{
COMPARISON OF VOLATILE AND PHENOLIC COMPOSITION OF COMMERCIAL AND EXPERIMENTAL CIDERS
}

\author{
Rita Riekstina-Dolge ${ }^{1^{*}}$, Zanda Kruma ${ }^{2}$ \\ I* Department of Nutrition, Faculty of Food Technology, Latvia University of Agriculture, Rigas iela 22, Jelgava, Latvia, \\ e-mail: rita.riekstina@llu.lv \\ ${ }^{2}$ Department of Food Technology, Faculty of Food Technology, Latvia University of Agriculture, Rigas iela 22, Jelgava, Latvia
}

\begin{abstract}
In the study five ciders produced in Latvia, three in France, and one sample from each - Ireland, Finland, South Africa were tested. The best 10 samples differing by raw materials, fermentation and maturation technology were selected from experimentally produced ciders. The total phenolic content was determined spectrophotometrically, but volatile compounds were analysed using SPME followed by GC/MS. The total phenolic content in commercial ciders is from $324 . \mathrm{mg} \mathrm{L}^{-1}$ to $3831.33 \mathrm{mg} \mathrm{L}^{-1}$ and significantly higher content in ciders produced in France. In the experimental ciders the total phenolic content was similar: from 793 to $3399 \mathrm{mg} \mathrm{L}^{-1}$. A lower content of volatile substances was identified in French ciders, while the highest content in the cider produced in Latvia. The main classes of identified volatiles were alcohols (6.53-74.05\%), and esters (18.81-73.61\%), with the most characteristic ones being ethyl carpylate, hexyl acetate, ethyl hexanoate, 3-methylbutyl acetate and ethyl decanoate. Experimental ciders matured with lactic acid bacteria Oenococcus oeni and oak chips showed a content of volatile compounds similar to that of French ciders. Experimental cider sample made from the crab variety 'Kerr', in its turn, showed a profile of volatile compounds similar to Latvian ciders.
\end{abstract}

Keywords: experimental cider, commercial cider, total phenolic, volatile compounds.

\section{Introduction}

Nowadays in Latvia small wine and cider producing companies are developing rapidly and it is important to develop best technological conditions. Cider is low alcoholic drink made by fermentation of apple juices. In Latvia there are no long cider making traditions and consumers are likely to recognise it by drink produced in large companies being heavily carbonated and having sweet taste. For successful acceptation of drink from consumers it is necessary to develop cider with good sensory characteristics. Odour and flavour are the most important quality attributes of alcoholic beverages, parameters determining the preferences of potential consumers. The development of these attributes throughout the technological process is influenced by the different and complex steps: selection of raw material, fermentation process and maturation or ageing (Antón-Díaz et al., 2016) Mastering the quality and the repeatability of production needs a better understanding of the way cider components interact to construct the final sensory characteristics of cider flavour (Symoneaux, 2015). For evaluation it is necessary to compare the quality parameters of experimental and commercial ciders available in retailing. Cider is produced from sharp, bitter sharp, bittersweet and sweet cider apples, and classification is based on apple sensory properties, acid and phenolic content and different apple varieties blends made perfect balance between sweetness and tartness (Lea, Drileau, 2003). Traditionally, cider makers have a preference for specific cider apple varieties -'crab apples', popular in western England, north-western France and northern Spain. Latvian producers mostly produce cider from culinary and / or dessert apples. In cider production, regardless the selected variety of apples or blends, it is more important to select the most suitable technological methods of cider fermentation, including the selection of the best pure yeast culture and maturation conditions, which ensures a basis for a high-quality end product with the best sensory characteristics.

Polyphenols play important role in the cider quality as they are related to the colour, bitterness and astringency, whose balance defines the overall mouthfeel of the beverage (Lea, Drilleau, 2003; AlonsoSalces et al., 2004) and the highest content is in ciders made from crab apples varieties (Riekstina et al., 2014). Research into the use of dessert apples alone for cider production has suggested they are less suitable due to their chemical attributes (Kuhn, 1994), yet these varieties fill an important volume gap due to their availability compared to traditional cider apple varieties (Girschik et al., 2017). Composition of volatile compounds of cider depends from many technological aspects. The study of volatile compounds can provide significant information about the raw materials and technological processes employed in the fermentation to guarantee cider quality and avoid financial losses (Pizarro et al., 2009). Volatiles identified in wines are usually dominated by fermentation products, the flavour compounds underlying the so-called 'yeast bouquet'; ethyl esters, acetate esters, fusel alcohols, carbonyls, and volatile fatty acids, are secondary metabolites synthesized by a wide range of microbial species and upon winemaking practices contribute to wine flavour (Romano et al., 2003). Malolactic fermentation significantly affects the sensory characteristics of cider and Oenococcus oeni can contribute significantly to the formation of volatile aroma compounds in white wine (Knoll et al., 2011). The aroma compounds of cider can be increased by maturation with oak chips (Fan et al., 2006) and chip roasting in various ways positively affects the amount of volatile substances in cider and oak phenolic may provide enhancement effects on wine aging systems with a significant improvement in the wine's colour, aroma and taste (Zhang et al., 2015). The aim of the current research was to compare the qualitative and quantitative content of 
phenolic and volatile compounds in commercial and experimental ciders.

\section{Materials and Methods}

\section{Cider samples}

Ten experimental ciders were selected from the series of studies for cider quality improvement (Table 1) and 11 commercial ciders from five different countries (Table 2) were analysed in the study.

The experimental ciders differed by used apple varieties, yeast strains, blending and maturation conditions. All the cider samples were stored in a refrigerator at $4 \pm 1{ }^{\circ} \mathrm{C}$ for providing constant conditions.

\section{Determination of total phenolic content}

The total polyphenol concentration was determined spectrophotometrically according to the Folin-Ciocalteu colometric method (Singleton et al., 1999).

Cider was diluted with ethanol / acetic acid solution in proportion 1:20 (v/v). Ethanol / acetic acid solution was prepared using ethanol (98\% vol.) and acetic acid water solution $(2.5 \%)$ in ratio $10: 90(\mathrm{v} / \mathrm{v}) .0 .5 \mathrm{~mL}$ of aliquot was mixed with $0.25 \mathrm{~mL}$ Folin-Ciocalteu reagents, after 3 minutes $1 \mathrm{~mL} 20 \% \quad \mathrm{Na}_{2} \mathrm{CO}_{3}$ and $3.25 \mathrm{~mL}$ distilled water were added. Samples were heated for $10 \mathrm{~min}$ at $70{ }^{\circ} \mathrm{C}$ and kept for 30 minutes at $18 \pm 2{ }^{\circ} \mathrm{C}$ temperature. The absorbance was measured at $765 \mathrm{~nm}$ using a spectrophotometer JENWAY 6300. Total phenols were expressed as gallic acid equivalents $\left(\mathrm{mg} \mathrm{L}^{-1}\right)$.

Determination of volatile aroma compounds
Volatiles from ciders were extracted using solid phase microextraction (SPME). $5 \mathrm{~g}$ of sample were weighed in a $20 \mathrm{~mL}$ headspace vial and capped with a septum. A divinylbenzene / carboxen / polydimethylsiloxane (DVB / Car / PDMS) fiber (Supelco Inc., Bellefonte, PA, USA) was used for headspace SPME sampling. SPME parameters were: incubation time $30 \mathrm{~min}$, extraction temperature $22 \pm 2{ }^{\circ} \mathrm{C}$, extraction duration $30 \mathrm{~min}$, desorption $15 \mathrm{~min}, 250{ }^{\circ} \mathrm{C}$. For the analysis of the SPME extracts, a Perkin Elmer Clarus 500 GC / MS and an Elite-Wax ETR $(60 \mathrm{~m} \times 0.25 \mathrm{~mm}$ i.d.; DF $0.25 \mu \mathrm{m})$ was used. Working conditions were as follows: injector $250{ }^{\circ} \mathrm{C}$; transfer line to MSD $260{ }^{\circ} \mathrm{C}$; oven temperature start $50{ }^{\circ} \mathrm{C}$, hold $2 \mathrm{~min}$, programmed from 50 to $100{ }^{\circ} \mathrm{C}$ at $5^{\circ} \mathrm{C} \mathrm{min}^{-1}$ hold $5 \mathrm{~min}$, and from 100 to $210^{\circ} \mathrm{C}$ at $5^{\circ} \mathrm{C} \mathrm{min}{ }^{-1}$, hold $15 \mathrm{~min}$; carrier gas

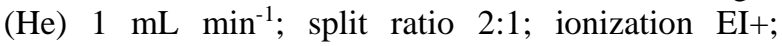
acquisition parameters in full scan mode: scanned $\mathrm{m} / \mathrm{z}$ 40-300. Compounds were identified by comparison of their mass spectra with mass spectral libraries (Nist98), and by calculation of linear retention indexes and comparison with literature data. All analyses were performed in triplicate. As a quantitative measure, the share in the total GC peak area for each compound is given.

Statistical analysis

Each determination was performed in triplicate and results are expressed as mean $\pm \mathrm{SD}$. The calculations were carried out using software MS Excel, SPSS 17.0 and statistical software programme Multibase 2014.

Characterization of experimental cider samples

\begin{tabular}{llc}
\hline Abbrev. & \multicolumn{1}{c}{ Characterization } & Alc., vol. \% \\
\hline A & Made from variety 'Auksis' apples & $5.5 \pm 0.2$ \\
K & Made from variety 'Kerr' apples & $5.1 \pm 0.2$ \\
$71 B-112$ & Fermented with 71B-112 yeast strains & $5.4 \pm 0.1$ \\
EC-1118 & Fermented with EC-1118 yeast strains & $5.9 \pm 0.1$ \\
LP_2_BF & Blended-fermented var. - 'Auksis' : 'Lietuvas Pepins' : 'Kerr' (2:1:2) & $5.4 \pm 0.1$ \\
R_2_BF & Blended-fermented var. - 'Auksis': 'Remo' : 'Kerr' (2:1:2) & $5.3 \pm 0.1$ \\
DI_1_BF & Blended-fermented var. - 'Auksis' : DI-9-4-14 :'Kerr' (1:1:1) & $5.6 \pm 0.2$ \\
M & Cider with added lactic acid bacteria & $5.6 \pm 0.2$ \\
Ch & Matured with unroasted oak chips & $5.5 \pm 0.3$ \\
RCh & Matured with medium roasted chips & $5.5 \pm 0.2$ \\
\hline
\end{tabular}

Characterization of commercial cider samples

\begin{tabular}{lll}
\hline Abbrev. & \multicolumn{1}{c}{ Name / Producer / Country } \\
\hline C1 & Cidre Bouche Brut De Normandie / Calvados Christian Drouin Ltd / France \\
C2 & Cidre Bouche Doux Lieblich / Cidrerie du Val de Vire Ltd / France \\
C3 & Cidre Bouche Pierre Huet / Calvados Pierre Huet Ltd / France \\
C4 & Bulmers Original Irish Cider / Bulmers Ltd / Ireland \\
C5 & Upcider apple cider / Harvall Ltd natural / Finland \\
C6 & Savanna dry premium cider / Distell Group Ltd/ South Africa \\
C7 & Abavas sidrs / Milli Ltd / Latvia \\
C8 & Abavas sidrs / Milli Ltd / Latvia \\
C9 & Sabiles sidrs / Kron,strauts Ltd / Latvia \\
C10 & Lucky Dog Apple / Latvijas balzams JSC / Latvia \\
\hline
\end{tabular}




\section{Results and Discussion}

\section{Phenolic compounds}

The total phenolic content in commercial ciders varied from 324. $\mathrm{mg} \mathrm{L}^{-1}$ (sample C10) to $3831 . \mathrm{mg} \mathrm{L}^{-1}$ with the highest content in the sample $\mathrm{C} 2$ (Fig. 1). The total phenolic content in experimental ciders was similar ranging from $793 \mathrm{mg} \mathrm{L}^{-1}$ in sample fermented with Saccharomyces bayanus yeast strains (EC-1118) to $3399 \mathrm{mg} \mathrm{L}^{-1}$ in sample produced from crab variety 'Kerr' apple (sample K).

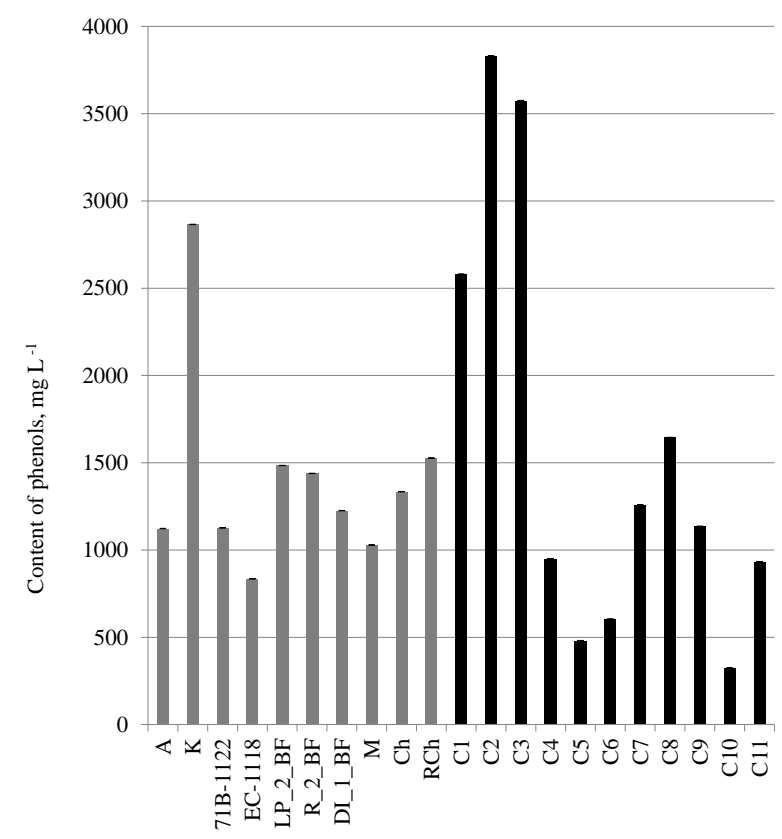

Samples

Figure 1. Total phenolic content in commercial and experimental ciders

The total phenolic content of ciders produced in France (samples C1, C2, C3) was higher that corresponded to the findings of Alonso-Salcese et al. (2005), where the total phenolic content in French ciders was 143-2488 $\mathrm{mg} \mathrm{L}^{-1}$, it was much less in Basque ciders, namely $24-331 \mathrm{mg} \mathrm{L}^{-1}$. Phenolic content of cider is mainly dependent on the used apple varieties and cider making technology. Cider making process (added enzyme, centrifugation, filtration, and clarification) as a result of the French cider is partially reduced procianidins content, because of their ability to precipitate proteins and interact with the cell wall polysaccharides (Alonso-Salce et al., 2004).

Comparing the phenolic content of ciders was carried out by cluster analysis. The first clusters comprise ciders produced in France C2 ("Cidre Bouche Doux Lieblich") and C3 ("Cidre Bouche Pierre Huet") with the highest total phenolic content, followed by the second cluster, which comprises C1 ("Cidre Bouche Brut De Normandie") and experimental cider of apple variety 'Kerr'. The third cluster includes several commercial ciders from big manufactories and all other experimental ciders and ciders made in small Latvian wineries providing similar phenolic content. The fourth cluster includes commercial ciders C5 ("Upcider apple cider natural"), C6 ("Savanna dry Premium cider") and C10 ("Lucky Dog Apple") that are known as sparkling ciders with distinct aroma and sweet taste.

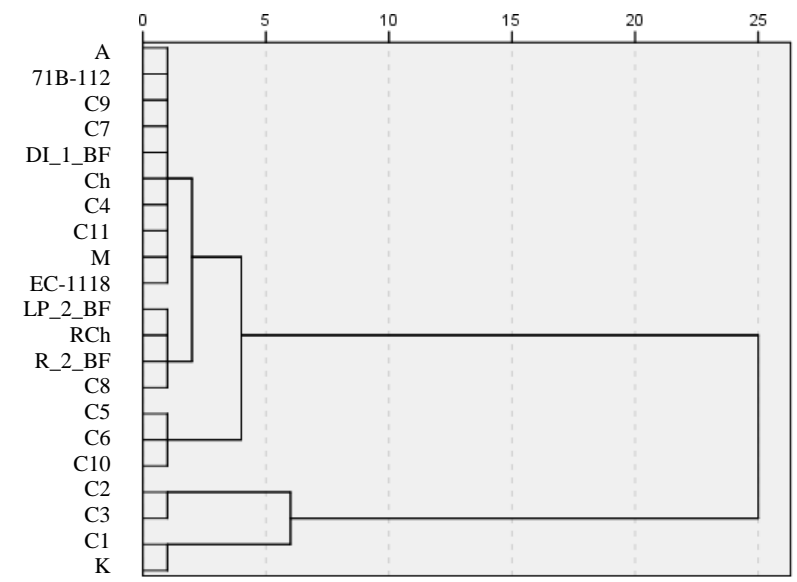

Figure 2. Division of the commercial and experimental ciders in clusters based on phenolic content

The fourth cluster comprises $\mathrm{C} 1$ cider and cider of experimental apple variety 'Kerr'. It is possible to conclude that phenolic contents both of commercial ciders and experimental ciders were similar due to the used apple varieties and producing technologies. The ciders contained higher phenolic contents and ciders made of crab variety apples contained a similar amount of phenolic.

\section{Volatile compounds}

The analysis of the content of volatile compounds in commercial ciders identified 33 volatile compounds and 21 in experimental ciders.

In French ciders there was identified the smallest peak area of volatile compounds with a total of the $140010^{5}$ PAU in sample C2 and $2147 \times 10^{5}$ PAU in sample C1. The highest volatile content was in the sample LP_2_BF with total of the $19710.43 \times 10^{5}$ PAU and R_2_BF with total of the $18750.3 \times 10^{5}$ PAU. These samples were made from three apple varieties, where the largest proportion was of apple varieties 'Auksis' and 'Kerr'.

The major volatile compounds in all samples are alcohols and esters. Volatile alcohol percentage differed from $6.5 \%$ (sample C10) to $74.1 \%$ (sample C9). Ethanol, 3-metibutan-1-ol and phenylethylalcohol are typical volatile alcohols in commercial ciders, and similar compounds have also been identified in the experimental ciders. 3-methylbutane-1-ol is a typical volatile alcohol in cider produced in China. In turn, hexane-1-ol is a compound with fruit characteristic and formed from linoleic acid oxidation (Ledauphin et al., 2003). The ester compound content as a percentage of the total volatile compounds cider samples ranged from $18.8 \%$ (sample C3) to $73.6 \%$ (sample C5). Typical cider esters are acetates and ethyl esters that make up the fruity cider flavoured. Ethylcapriolate, hexylacetate, octoate, 3-metilbutilacetate and ethyldecanoate are the main compounds in the typical commercial ciders and specific to the experimental ciders. 


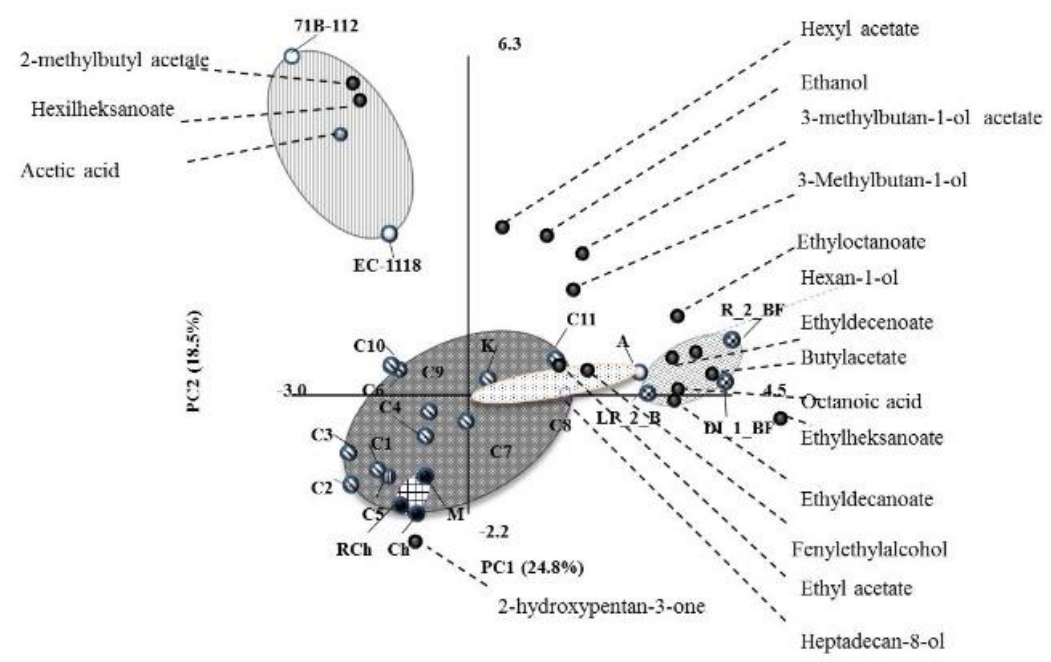

Figure 3. Principal component analysis of volatile compounds of experimental and commercial ciders

In commercial and experimental ciders were identified four acids, namely acetic acid in samples C3 and C6, sorbic acid in samples $\mathrm{C} 5$ and $\mathrm{C} 10$, decanoic acid in samples $\mathrm{C} 1, \mathrm{C} 2, \mathrm{C} 5$ and $\mathrm{C} 10$, while octanoic acid, characterized by a weak, fruity aroma (Villiere et al., 2012) was identified in all samples, except for samples C3. Sorbic acid is an organic acid, for use in foods and beverages as a preservative, which is characterized by mildly spicy flavour. Sorbic acid is widely used as a mould inhibitor, a variety of food and flavour formation of sorbic acid catabolism with sorbate resistant yeast and mould strains (Gürbüz et al., 2011).

Factor analysis following summative dispersion results suggested that the first two factors explained $24.8 \%$, and $18.5 \%$, of total set of variables (Fig. 3). The high dispersion of volatiles in experimental and commercial ciders represents differences in raw materials and technologies. Ciders matured with lactic acid bacteria Oenococcus oeni and oak chips had similar content of volatile substances with those of French ciders. French ciders are characterized by lactic acid fermentation that occurs during maturing in oak barrels (Swaffield et al., 1997). The sample of crab variety 'Kerr' presented a similar profile of volatile compounds with that of the samples from ciders produced in Latvia - C7 ("Sabiles sidrs") and C9 ("Abavas sidrs").

\section{Conclusions}

The results showed that in terms of phenolic content and the content of volatile compounds, experimental ciders and commercial ciders were similar. The highest phenolic content was in French ciders and ciders of 'Kerr' variety apples. Ciders matured by adding lactic acid bacteria Oenococcus oeni and oak chips revealed similar content of volatile compounds as French ciders. But the sample of crab variety 'Kerr' ciders had a similar profile of volatile compounds with ciders C7 ("Abavas sidrs") and C9 ("Sabiles sidrs") produced in Latvia.

\section{Acknowledgment}

The research has been done within the National Research Programme "Sustainable use of local resources (earth, food, and transport) - new products and technologies (Nat Res)" (2010-2013) project no. 3. „Sustainable use of local agricultural resources for development of high nutritive value food products (Food)" and ESF project "Support for the Implementation of LLU doctoral studies" contracts No 2009/0180/1DP/1.1.2.1.2/09/IPIA/VIAA/017.

Authors also acknowledge Institute of Horticulture, Latvia University of Agriculture for supply with apples.

\section{References}

1. Alonso-Salces R.M., Barranco A., Abad B., Berrueta L.A., Gallo B., Vicente. F. (2004) Polyphenolic profiles of Basque cider apple cultivars and their technological properties. Journal of Agricultural and Food Chemistry, Vol. 52, p. 2938-2952.

2. Alonso-Salces R.M., Herrero C., Barranco A., Berrueta L.A., Gallo B., Vicente F. (2005) Classification of apple fruits according to their maturity state by the pattern recognition analysis of their polyphenolic compositions. Food Chemistry, Vol. 93 (1), p. 113-123.

3. Antón-Díaz M. J., Suárez Valles B., Mangas-Alonso J. J., Fernández-García O., Picinelli-Lobo A. (2016) Impact of different techniques involving contact with lees on the volatile composition of cider. Food Chemistry, Vol 190, p. 1116-1122.

4. Buglass A. J. (2011) Cider and Perry. In: Handbook of Alcoholic Beverages: Technical, Analytical and Nutritional Aspects. J. Alan Chichester (eds): John Wiley \& Sons, p. 231-265.

5. Girschik L., Jones J.E., Kerslake F. L., Robertson M., Dambergs R.G., Swarts N. D. (2017) Apple variety and maturity profiling of base ciders using UV spectroscopy. Food Chemistry, Vol. 228, p. 323-329.

6. Gürbüz O., Değirmencioğlu N., Yıldız S. (2011) Quantitative analysis of sorbic acid in cereal products using GC-MS- SIM 10/2011. In: Proceeding of 6th International Congress Flour-Bread'11 \& 8th Croatian Congress of Cereal Technologists, Opatija, Croatia, p. 65-75. 
7. Pizarro C, Pérez-del-Notario N., González-Sáiz J. M. (2009) Headspace solid-phase microextraction for direct determination of volatile phenols in cider. Journal of Separation Science, Vol 32 (21), p. 3746-3754.

8. Knoll C., Fritsch S., Schnell S., Grossmann M., Rauhut D., $\mathrm{du}$ Toit M. (2011) Influence of $\mathrm{pH}$ and ethanol on malolactic fermentation and volatile aroma compound composition in white wines. Food Science and Technology, Vol. 44 (10), p. 2077-2086.

9. Kuhn G. D. (1994) Making, handling and marketing safe, high-quality apple cider. USA: Pennsylvania State University, p.13.

10. Lea A. G. H., Drilleau J. F. (2003) Cidermaking. In: Fermented Beverage Production. A.G.H. Lea, J. R. Piggot (eds). London: Blackie Academic and Professional,p. 5987.

11. Ledauphin J., Guichard H., Saint-Clair J. F., Picoche B., Barillier D. (2003) Chemical and sensorial aroma characterization offreshly distilled calvados. Identification of volatile compounds and key odorants. Journal of Agriculture and Food Chemistry, Vol. 51, p. 433-442.

12. Riekstina-Dolge R., Kruma Z., Dimins F., Straumite E., Karklina D. (2014) Phenolic composition and sensory properties of ciders produced from Latvian apples.
Proceedings of Latvia University of Agriculture, Vol. 31, p. 326.

13. Romano P., Fiore C., Paraggio M., Caruso M., Capece A. (2003) Function of yeast species and strains in wine flavour. Journal Food Microbiology, Vol. 86, p. 169-180.

14. Swaffield C. H., Scott J. A., Jarvis B. (1997) Observations on the microbial ecology of traditional alcoholic cider storage vats. Food Microbiology, Vol.14, p. 353-361.

15. Symoneaux R., Guichard H., Le Quéré J. M., Baron A., Chollet S. (2015) Could cider aroma modify cider mouthfeel properties? Food Quality and Preference, Vol. 45, p.11-17.

16. Villière A., Arvisenet G., Lethuaut L., Prost C., Sérot T. (2012) Selection of a representative extraction method for the analysis of odorant volatile composition of French ciders by GC-MS-O and GCxGC-TOF. Food Chemistry, Vol. 131, p. 1561-1568.

17. Fan W., Xu Y., Yu A. (2006) Influence of oak chips geographical origin, toast level dosage and aging time on volatile compounds of apple cider. Journal Institute Brewery, Vol. 112 (3), p. 255-263.

18. Zhang B., Cai J., Duan C. Q., Reeves M. J., He F. (2015) A Review of polyphenolics in oak woods. International Journal of Molecular Sciences, Vol. 16, p. 6978-7014. 